\title{
Production and Use of Liquid Biofuels for Heating Purposes
}

\author{
Nowak Krzysztof ${ }^{*}$, Kut Paweł ${ }^{1}$ \\ 1 Rzeszow University of Technology, Department of Heat Engineering and Air Conditioning, Al. Powstańców \\ Warszawy 6, 35-959 Rzeszów, Poland \\ *Corresponding author's e-mail: krzynow@prz.edu.pl
}

\begin{abstract}
The increased consumption of fossil fuels and energy result directly from the economic development of countries around the world. The economic development also affects the price of fuels, the cost of energy production and, above all, the progressing degradation of the natural environment. Therefore, increasing emphasis is placed on the possibility of efficient generation of heat and electricity from alternative fuels. Biofuels are obtained from the biomass subjected to the biochemical or thermochemical processes. They may be in solid, liquid or gaseous form. They are a very good alternative, enabling to become independent of the fossil energy sources such as coal, oil or gas. The locally produced biofuels can be a cheap energy carrier and also contribute to the climate protection. The main purpose of this article was to present the general characteristics of liquid biofuels. The methods and processes of their production as well as the possibilities of using them in the heating processes are discussed. The preliminary results of comparison of energy values for bioethanol from different distillation stages on laboratory scale were also presented. On the basis of literature review and own research results it can be noticed that the liquid biofuels are an interesting alternative to the conventional fuels.
\end{abstract}

Keywords: biofuel, biofuel production, bioethanol

\section{INTRODUCTION}

Fuels, as energy carriers have a significant impact on the functioning of society. The dependence on fuels and thus energy is directly proportional to the development of civilization. With their participation, it is possible to function and develop, among others, industry, energy, transport and industrial agriculture. Random suspension of energy supplies can often have irreversible and tragic consequences. Limitation or cessation of energy supplies may lead to conflicts, and ultimately to the end of the functioning of the civilization in its present form. Therefore, it is necessary to create a long-term energy policy. It is important to ensure a balance between the security of raw material supply, efficiency of economic processes and increasingly stringent environmental protection requirements. The supporters of fossil fuels believe that they have enabled us to achieve the current level of civilization development.
According to them, the renewable energy sources are not able to effectively cover the demand for fossil fuels. On the other hand, the non-renewable energy sources contribute to the environmental degradation and climate change. Moreover, their resources are becoming depleted (Nowak, 2014; Nowak, Bukowska, Proszak-Miąsik, Rabczak, 2017; Proszak-Miąsik and Rabczak 2018).

Therefore, there is a growing emphasis on the possibility of efficient generation of heat and electricity from alternative sources. These include the biofuels obtained from the biomass subjected to the biochemical or thermochemical processes. They can be in the solid, liquid or gaseous form. Biofuels are an interesting alternative, owing to which it is possible to reduce the consumption of fossil energy sources such as coal, oil or gas. The locally produced biofuels allow for partial independence from the external supplies and can also be a cheap energy carrier, contributing to climate protection. The work continues to focus on 
the liquid biofuels as renewable energy sources. Particular attention was paid to the production of bioethanol and its possible applications.

\section{Liquid biofuels}

The liquid biofuels are groups of products that are formed by the biodegradation of substances called biomass produced by the living organisms and microorganisms. Biofuels are particularly important for the global economy, due to the need to meet the energy needs and also due to the depletion of conventional fuels. The main types of liquid biofuels are bioethanol, biomethanol and biodiesel as well as their blends with petrol or diesel. Table 1 presents the types of biofuels, the raw materials necessary for their production, the type of conversion process leading to their obtaining and the basic application (Lewandowski, Ryms, 2013)

\section{Characteristics of bioethanol}

Bioethanol, otherwise known as ethyl alcohol in dehydrated form, is used as a fuel, and a substitute or additive to other fuels. It is also an important raw material in the chemical, pharmaceutical and food industry (Lewandowski, Ryms, 2013). Bioethanol may be used in its pure form and as a mixture with other alcohols or with other fuels, mineral oil derivatives.

At room temperature, bioethanol is a colourless, flammable liquid with a characteristic smell and taste. It has a density of $789.4 \mathrm{~kg} / \mathrm{m}^{3}$, a boiling point under normal conditions of $78.4^{\circ} \mathrm{C}$ and a combustion heat of approximately $30 \mathrm{MJ} / \mathrm{kg}$. It burns in the open air with a bluish flame. It is produced in the process of alcoholic fermentation from wholesome plant products containing both simple sugars and polysaccharides, such as cereals, potatoes, sugar cane, energy crops, or from waste, e.g. in the form of paper, wood panels. The process of bioethanol production takes place in distilleries and consists in converting sugar into alcohol and carbon dioxide with the use of the enzymes contained in yeasts, according to the following reaction:

$$
\mathrm{C}_{6} \mathrm{H}_{12} \mathrm{O}_{6} \rightarrow 2 \mathrm{C}_{2} \mathrm{H}_{5} \mathrm{OH}+2 \mathrm{CO}_{2}
$$

The production of bioethanol as a fuel brings many benefits, including the reduction of environmental degradation, activation of agriculture and, above all, reduction of the costs related to the oil imports. Due to its low emissions in the combustion process and its production from renewable raw materials, bioethanol is considered an environmentally friendly fuel. Moreover, the analyses of the total energy consumption needed for the production of bioethanol show that the energy used for its production is lower than the energy obtained from the combustion process, and therefore the balance of the process is positive and economically justified (Adams, Gallagher, Donnison, 2008; Gray, Zhao, Emptage, 2006; Lewandowski, Ryms, 2013).

\section{Bioethanol production methods}

Several bioethanol production methods are currently used. The simplest and most popular method is ethanol fermentation, which uses the micro-organisms capable of converting simple sugars into ethyl alcohol under anaerobic

Table 1. Sources of liquid biofuels and their energy use

\begin{tabular}{|l|l|l|l|}
\hline \multicolumn{1}{|c|}{ Biofuel } & \multicolumn{1}{|c|}{ Raw material } & \multicolumn{1}{c|}{ Conversion process } & \multicolumn{1}{c|}{ Application } \\
\hline Bioethanol & $\begin{array}{l}\text { Products containing monosaccharides } \\
\text { or polysaccharides, inter alia: molasses, } \\
\text { cereals, potatoes, Jerusalem artichokes, } \\
\text { sugar beet, sugar cane, energy crops, } \\
\text { Miscanthus }\end{array}$ & $\begin{array}{l}\text { Depending on the raw material: } \\
\text { pre-treatment, hydrolysis, } \\
\text { fermentation, distillation }\end{array}$ & $\begin{array}{l}\text { Gasoline substitute or } \\
\text { additive }\end{array}$ \\
\hline Biomethanol & energy crops, Miscanthus & $\begin{array}{l}\text { Gasification or synthesis of } \\
\text { methanol }\end{array}$ & Fuel cells \\
\hline Vegetable oil & Rape, sunflower, soybean & Pressing and refining & $\begin{array}{l}\text { Substitute or additive for } \\
\text { diesel }\end{array}$ \\
\hline Biodiesel & Rape, sunflower, soybean & $\begin{array}{l}\text { Substitute or additive for } \\
\text { diesel }\end{array}$ & $\begin{array}{l}\text { Substitute for petrol or } \\
\text { diesel }\end{array}$ \\
\hline Biooil & Energy crops, Miscanthus & Pyrolysis & \\
\hline
\end{tabular}


conditions. The ethanol fermentation method is used on an industrial scale in distilleries. The production process itself can be divided into three stages:

- preparation of the raw material - it consists in the enzymatic decomposition of complex sugars into monosaccharides by hydrolysis;

- ethanol fermentation - consists in converting the monosaccharides into ethyl alcohol with $\mathrm{CO}_{2}$ separation;

- alcohol separation - consists in separating eth$y l$ alcohol from the fermentation residue during distillation, dehydration and rectification.

Figure 1 shows the block diagram of obtaining alcohol in a grain distillery.

In simple alcoholic distillation, a mixture of ethanol and water at a concentration of approximately $95.6 \%$ is obtained. In order to obtain an anhydrous alcohol of 99.5-99.9\%, azeotropic distillation in the ethanol-water-benzene system is used. The use of a small amount of benzene initially causes the process of boiling the triple azeotrope benzene - ethanol - water, then the azeotrope ethanol - benzene, and in the last stage of the distillation process - pure anhydrous ethanol. Anhydrous ethanol is highly hygroscopic and must therefore be stored in tightly closed vessels to prevent water from being absorbed from the air.

The alcoholic fermentation method is also used for the occasional production of ethyl alcohol to meet private needs, both energy and food. Unfortunately, the production of ethyl alcohol without a registered activity and a relevant licence is illegal in Poland. In spite of this, the alcohol distillation equipment is available on the market to obtain the ethanol of purity and concentration similar to that produced in distilleries.
Figure 2 presents a diagram of a simple system for distillation.

The alcohol produced by the home-made methods is most often made from water, food sugar and distillery or food yeast. All ingredients are mixed in fixed proportions in a suitable vessel with a fermentation tube. The mash produced is set aside until the fermentation process stops. The mash is then poured into a vessel in which the cooking and distillation process takes place. In the first stage of production, the so-called 'foreground' is obtained, i.e. alcohol with admixtures of the components with a lower boiling point than ethyl alcohol, including, among others, esters, aldehydes, organic acids and higher alcohols. In the second phase of production, pure ethyl alcohol is obtained. In the last production phase, a final fraction with a lower alcoholic strength is obtained, which may contain the components with a higher boiling point than the ethyl alcohol itself. Depending on the apparatus used, it is possible to obtain high quality bioethanol with an alcohol concentration above $90 \%$, suitable for both energy and food processes.

Bioethanol can also be produced from the lignin-cellulose materials, such as straw, maize or grass. One of the best known methods of converting such materials into alcohol is the Iogen technology. This method is based on a thermal, chemical and biochemical combination. The production process starts with chopping and grinding the raw material, which is then directed to the reactor. There, it is subjected to thermal treatment at a temperature of $180-250^{\circ} \mathrm{C}$ in the presence of water vapour with a solution of $0.5-2 \%$ sulphuric acid. In the next stage, the pressure decreases rapidly. Enzymes are added to the material prepared

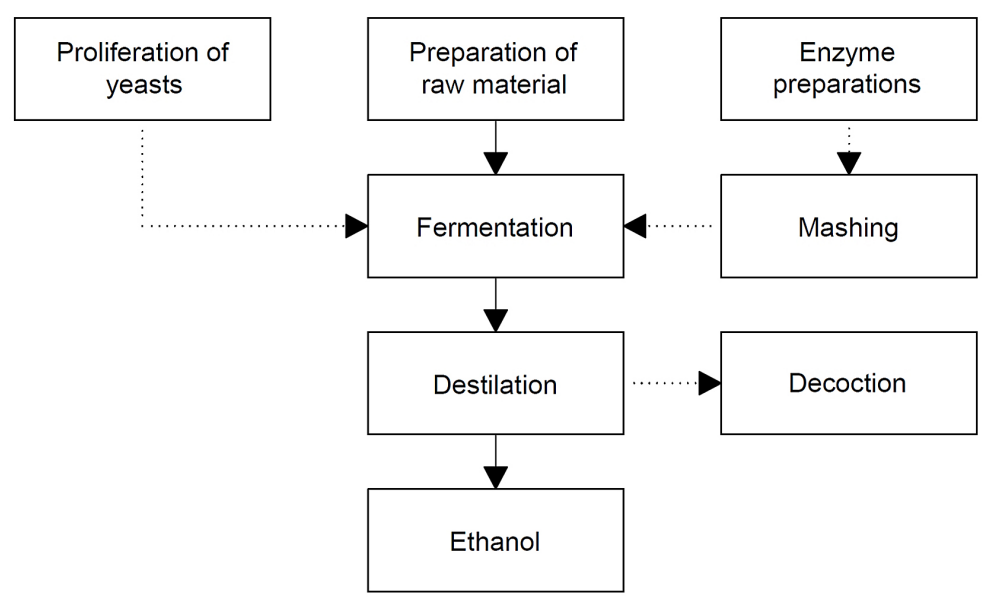

Fig. 1. Block diagram of obtaining alcohol in a grain distillery 


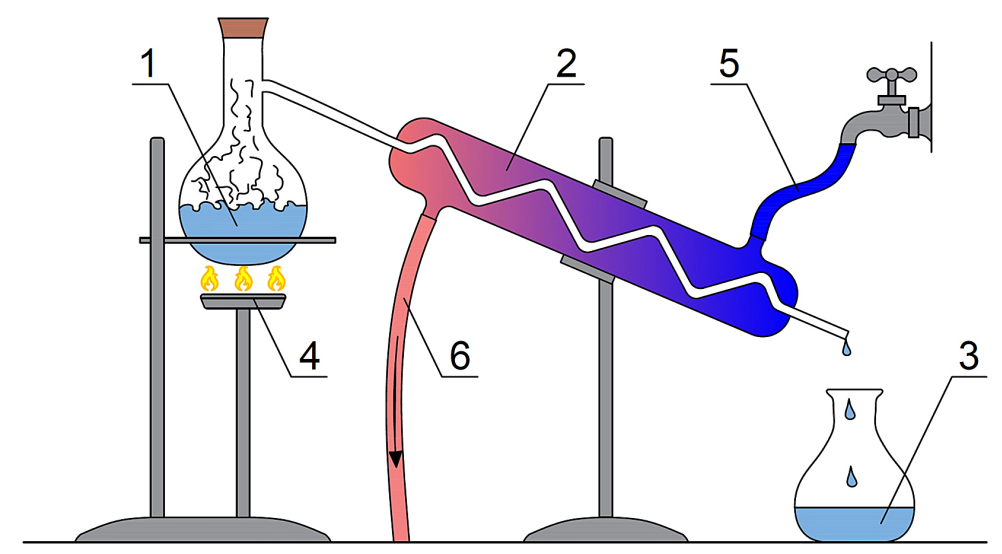

Fig. 2. Scheme of a simple system for distillation: 1 - mash, 2 - distiller, 3 - distillate (ethyl alcohol), 4 - burner or heater, 5 - cooling water supply, 6 - heated water outlet

in this way, the task of which is to break down hemicellulose and cellulose into simple sugars. After the hydrolysis is completed, the sediment is separated from the solution of the sugars obtained. This solution is directed to the fermenter, where yeast is added and the sugars ferment to ethanol. The resulting ethanol solution is distilled. The lignin present in the vegetable fibres, which remains after the process as a by-product, is processed and used as a fuel in the production of process steam and electricity, so that additional energy sources are not needed in the process.
Figure 3 shows the block diagram of the bioethanol production according to the Iogen technology.

Other techniques of bioethanol production described in textbooks and scientific publications are also known, such as: ICM technology, technology using water in the supercritical state, technology of BlueFire Ethanol Inc. using sulphuric acid for hydrolysis of plant biomass, or technology of Coskata Inc. using the gasification method (Kim, Dale, 2004; McMillan, 1997; Sarkar, Ghosh, Bannerjee, Aikat, 2012).

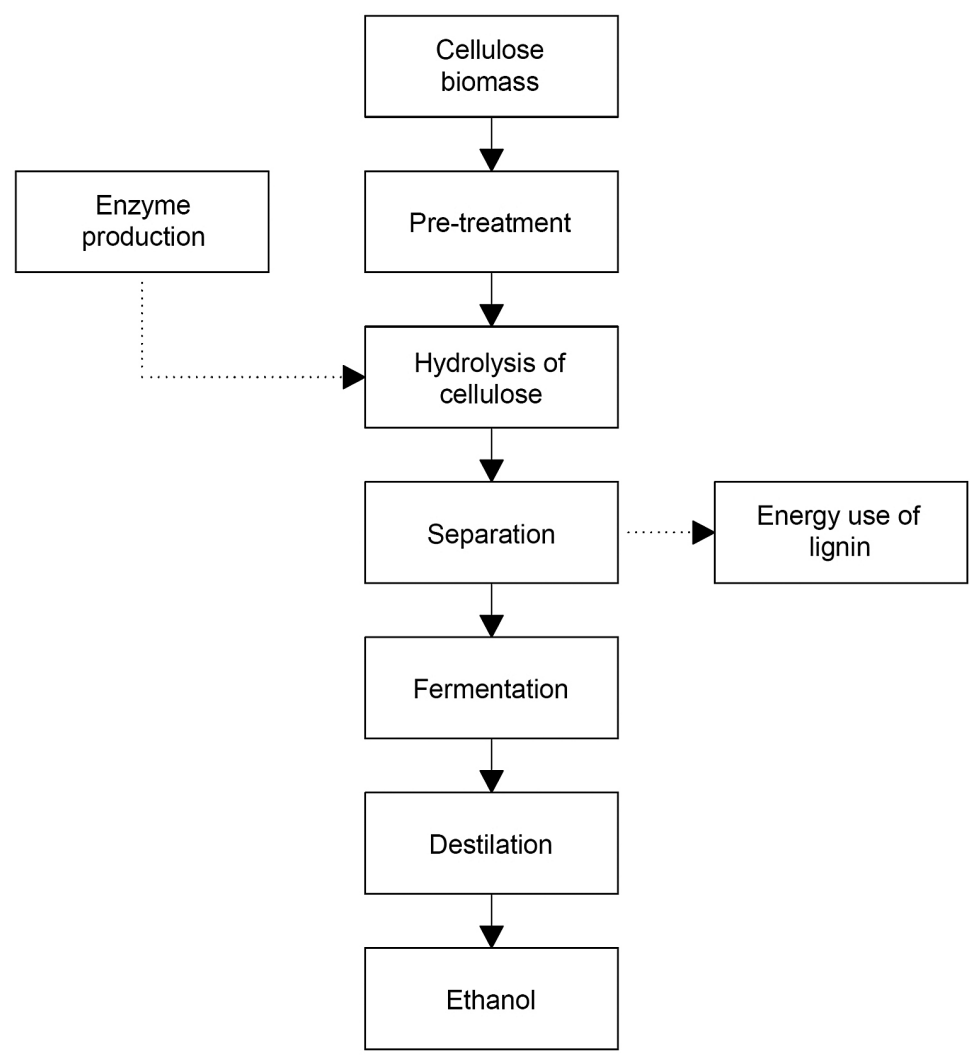

Fig. 3. Block diagram of bioethanol production according to the Iogen technology 


\section{Raw materials used for bioethanol production}

Bioethanol production is mainly based on the fermentation of products containing monosaccharides. The theoretical maximum yield of the ethanol production from such sugars is about $0.5 \mathrm{~kg} / \mathrm{kg}$. An example of a good raw material for the production of bioethanol is, among others, molasses, which is a by-product of the sugar production process. It contains about $40-55 \%$ sucrose. It comes in the form of a dark-brown alkaline syrup. Depending on the raw material from which it is made, cane and beet molasses, among others, are distinguished. Taking into account the fact that about 0.31 tonne of molasses is produced from 1 tonne of sugar, in 2018/2019 it was possible to produce about $650000 \mathrm{~kg}$ in Poland, which in turn corresponds to about $195000 \mathrm{~m}^{3}$ of bioethanol (Borychowski, Matuszczak, Stępień, 2019; KOWR, 2019; Lewandowski, Ryms, 2013). An obstacle in the use of molasses as a raw material for the production of bioethanol is a problem with the management of the distillery stock, as it cannot be used for the production of fodder but only for the production of potassium fertilisers.

Table 2 shows the examples of raw materials used for the bioethanol production. The production capacities and prices for individual raw materials are the values averaged over 2019 .

\section{Use of bioethanol}

Bioethanol is widely used in various economic sectors. It is employed in food industry, e.g. for the production of alcoholic beverages or as an additive in confectionery. It is also used in the pharmaceutical industry in the production of certain medicines and as a disinfectant. Bioethanol is a very good solvent used in the chemical industry for the production of varnishes, perfumes and as a preservative. An effective way to use bioethanol is to apply it in the energy processes. It is an interesting alternative to the conventional fuels used in the internal combustion engines. In 1975, industrial production of biobenzene E85, i.e. mixture of $85 \%$ ethanol and $15 \%$ petrol, was initiated in Brazil (Bednarz, 2008). Due to the higher octane number and lower combustion heat as compared to petrol, high percentage bioethanol mixtures or pure bioethanol can be used in the engines adapted for this purpose. Low percent bioethanol blends can be used in the majority of traditional engines, in many cases improving their performance. Moreover, the introduction of mixtures with low bioethanol content is much easier due to the possibility to use the existing fuel infrastructure and distribution network (Kruczyński, Gis, Stępień, Zin, 2018).

Bioethanol is also used as pure fuel in biofireplaces. The product of combustion in such a system is water vapour and carbon dioxide. Carbon dioxide is released in safe quantities for living organisms, while water vapour has a positive effect on air humidity in the building. No smoke is produced during the combustion of biofuel, therefore the bio-fireplaces can also be used in the rooms without installed combustion chimneys.

\section{Measurement of bioethanol combustion heat}

The heat of combustion of bioethanol samples produced with the fermentation method on the laboratory scale with the use of an electric heater distiller was measured. The percentage of alcohol in the biofuel was tested using a calibrated immersion alcohol meter. The combustion heat was measured with the Parr 6300 automatic calorimeter. According to the Parr guidelines, the

Table 2. List of raw materials and their production capacity characteristics (Lewandowski, Ryms, 2013; Marczak, 2012; Podlaski, 2007)

\begin{tabular}{|c|c|c|c|c|c|c|c|}
\hline Raw material & $\begin{array}{c}\text { Starch/sugar } \\
\text { content }\end{array}$ & $\begin{array}{c}\text { Ethanol } \\
\text { production } \\
\text { capacity }\end{array}$ & $\begin{array}{c}\text { Average } \\
\text { raw material } \\
\text { yields }\end{array}$ & $\begin{array}{c}\text { Production } \\
\text { capacity }\end{array}$ & $\begin{array}{c}\text { Average } \\
\text { raw material } \\
\text { prices }\end{array}$ & $\begin{array}{l}\text { Raw material } \\
\text { costs }\end{array}$ & $\begin{array}{c}\text { Raw material } \\
\text { costs per } \\
\text { production } \\
\text { unit }\end{array}$ \\
\hline & $\%$ & $\mathrm{dm}^{3} / \mathrm{kg}$ & $\mathrm{kg} / \mathrm{ha}$ & $\mathrm{m}^{3} / \mathrm{ha}$ & PLN/kg & PLN/ha & $\mathrm{PLN} / \mathrm{dm}^{3}$ \\
\hline Potatoes & 20 & 0.13 & 50000 & 6.25 & 1.00 & 50000 & 7.69 \\
\hline Rye & 60 & 0.38 & 2500 & 0.95 & 0.53 & 1325 & 1.39 \\
\hline Triticale & 60 & 0.38 & 3200 & 1.20 & 0.61 & 1952 & 1.61 \\
\hline Maize & 65 & 0.42 & 8000 & 3.36 & 0.68 & 5440 & 1.62 \\
\hline Sugar beet & 16 & 0.09 & 45000 & 4.05 & 0.12 & 5400 & 1.33 \\
\hline Molasses & 50 & 0.30 & - & - & 0.80 & - & 2.67 \\
\hline Sugar & 100 & 0.51 & - & - & 2.50 & - & 4.90 \\
\hline
\end{tabular}


samples of alcohols, i.e. volatile materials with boiling point below $180^{\circ} \mathrm{C}$, were protected in the crucible with a tape of known weight and combustion heat value. Table 3 shows the averaged results for the tested bioethanol samples from the first production phase (bioethanol 1) and the respective production phase (bioethanol 2). Both alcohols play their role as biofuel in the energy processes; however, due to their taste, only the bioethanol from the actual production phase is used for the food purposes. Table 3 presents the results for the analysed bioethanol samples. The alcohol concentration was measured at sample temperatures of $20^{\circ} \mathrm{C}$.

Table 3. Summary of results for the samples analysed

\begin{tabular}{|l|c|c|c|}
\hline \multicolumn{1}{|c|}{ Parameter } & Unit & Bioethanol 1 & Bioethanol 2 \\
\hline Temperature & ${ }^{\circ} \mathrm{C}$ & 20 & 20 \\
\hline $\begin{array}{l}\text { Alcohol content } \\
\text { of the sample }\end{array}$ & $\%$ & 94 & 94 \\
\hline Combustion heat & $\mathrm{MJ} / \mathrm{kg}$ & 28.24 & 27.28 \\
\hline
\end{tabular}

\section{CONCLUSIONS}

Liquid biofuels are groups of products resulting from the biomass processing. Biofuels play an important role in the global economy due to the need to meet energy needs and also due to the depletion of the conventional fuel resources. The basic types of liquid biofuels are bioethanol, biomethanol and biodiesel, as well as their blends with petrol or diesel oil. In this work, particular attention was paid to bioethanol. The raw materials from which bioethanol is produced and the methods of its production were discussed.

On the basis of the literature review, it can be seen that sugar beet is the most profitable of the mentioned raw materials in the process of bioethanol production. For every $1 \mathrm{dm}^{3}$ of production of a finished product, the cost of raw material amounts to about 1.33 PLN. The production of the bioethanol from rye is at a similar price level $\left(1.39 \mathrm{PLN} / \mathrm{dm}^{3}\right)$. Slightly higher costs of the raw material are in the case of triticale and maize (1.61 and $\left.1.62 \mathrm{PLN} / \mathrm{dm}^{3}\right)$. The most expensive raw material is potato, and interestingly, producing $1 \mathrm{dm}^{3}$ of ethanol is about 2.79 PLN more expensive in comparison with the regular white sugar available in every grocery store. The raw material for producing $1 \mathrm{dm}^{3}$ of bioethanol using molasses costs about 2.67 PLN. The prices of raw materials depend, among other things, on availability, current demand and supply, as well as on yield and thus the production efficiency, so it is difficult to estimate how production costs will develop in the future.

In the research part, the alcohol concentration and heat of combustion of the ethanol samples produced on a laboratory scale by means of an electric distiller were measured. The samples from the first and second stage of production were analysed.

Bioethanol from both production stages has an alcohol content of $94 \%$. The combustion heat of bioethanol from the first production stage is slightly higher than from the second production stage and is $28.24 \mathrm{MJ} / \mathrm{kg}$ and $27.28 \mathrm{MJ} / \mathrm{kg}$, respectively. This may be due to the higher content of lightweight, volatile flammable compounds.

On the basis of the literature review and own research results, it can be concluded that the liquid biofuels are an interesting alternative to the conventional fuels.

\section{REFERENCES}

1. Adams J. M., Gallagher J. A., Donnison I. S. 2008. Fermentation Study on Saccharina Latissima for Bioethanol Production Considering Variable PreTreatments. Journal of Applied Phycology, 21(5), 569-574.

2. Bednarz L. M. 2008. Ethanol, myth or fuel of the future?. Przemysł Chemiczny, tom 87, nr 8, 807-809.

3. Biuro Analiz i Strategii KOWR. 2019. Information on the situation on the sugar market.

4. Borychowski M., Matuszczak A., Stępień S. 2019. Sugar Market in Poland in the Context of the Support of Agricultural Policy. Current Situation, Trends and Projections. Acta Scientiarum Polonorum. Oeconomia, 4, 5-13.

5. Gray K. A., Zhao L., Emptage M. 2006. Bioethanol. Current Opinion in Chemical Biology, 10(2), 141-46.

6. Seungdo K., Dale B. E. 2004. Global Potential Bioethanol Production from Wasted Crops and Crop Residues. Biomass and Bioenergy 26(4), 361-75.

7. Kruczyński S. W., Gis W., Stępień Z., Zin D. 2018. Bioethanol as a fuel component for spark-ignition engines. Zeszyty Naukowe Instytutu Pojazdów / Politechnika Warszawska, z. 2/116.

8. Lewandowski W. M., Ryms M. 2013. Biofuels. Proecological renewable energy sources. Warszawa: Wydawnictwo WNT.

9. Marczak H. 2012. The importance of ethanol in 
the fulfillment of the obligation to use renewable fuels for transport. Polskie Towarzystwo Inżynierii Ekologicznej, Inżynieria Ekologiczna, Tom 28, 102-110.

10. McMillan J. D. 1997. Bioethanol Production: Status and Prospects. Renewable Energy, 10(2), 295-302.

11. Nowak K. 2014. Co-combustion biomass and carbon in energetic boilers. Inżynierii Lądowej, Środowiska i Architektury, z. 61, nr 3/II, 379-390.

12. Nowak K., Bukowska M., Proszak-Miasik D., Rabczak S. 2017. Emission of Air Pollutants in the Hot Water Production. IOP Conference Series: Materials
Science and Engineering, 245 (2017) 052032 doi:1 0.1088/1757-899X/245/5/052032

13. Podlaski S. ,2007. Sugar beet as raw material in production of ethanol. Gazeta Cukrownicza 115 (04), 126-130.

14. Proszak-Miąsik D., Rabczak S. 2018. Methods for Reducing Low Emissions from Heating Devices in Single- Family Housing. E3S Web of Conferences, 45:00069, 1-8.

15. Sarkar N., Ghosh S. K., Bannerjee S., Aikat K. 2012. Bioethanol Production from Agricultural Wastes: An Overview. Renewable Energy, 37(1), 19-27. 